\title{
PENGARUH KUALITAS PELYANAN TERHADAP INOVASI LAYANAN PT. POS INDONESIA SEBAGAI UPAYA MENJAGA EKSISTENSI DI ERA PERSAINGAN GLOBAL (Studi Kantor Pos Padang)
}

\author{
Mefdiza Randa, Aminar Sutra Dewi \\ Sekolah Tinggi Ilmu Ekonomi KBP \\ mefdizaranda35@gmail.com
}

\begin{abstract}
In this globalization era, every business is required to continue to innovate in order to remain competitive. Indonesian Post Company is one of the state that is required to continue to exist. Indonesian Post Company required to continue to innovate, especially in the field of customer services in order not to be abandoned. This study aims to describe and analyze the innovation of Indonesian Post Company. This research is descriptive research type with qualitative approach. Data collection techniques used in this study with interviews, observation and documentation. The theory used in this research is the theory of Zeithaml, Parasuraman \& Berry. The basis of the theory is the focus of this study is the physical Visibility, reliability, responsiveness, competence, credibility, and communication. The results showed innovations in service made by Indonesian Post Company to maintain its presence is still not maximal.
\end{abstract}

Keyword : service Quality, service Innovation, Global Competition.

\section{PENDAHULUAN}

Kualitas merupakan suatu kondisi dinamis yang berpengaruh dengan produk, jasa, manusia, proses dan lingkungan yang memenuhi atau melebihi harapan (Wardani, Sundarso, \& Warsono, 2013) dalam . Sehingga definisi kualitas pelayanan dapat diartikan sebagai upaya pemenuhan kebutuhan dan keinginan konsumen serta ketepatan penyampaiannya dalam mengimbangi harapan konsumen (Wardani et al., 2013).

Pesaingan bisnis dibidang jasa pengiriman barang di Indonesia saat ini semakin meningkat, seiring banyaknya perusahaan-perusahaan sejenis yang bergerak dibidang yang sama. Perusahaan-perusahaan yang saat ini eksis dalam bisnis jasa pengiriman barang di Indonesia antara lain Pos, JNE, TIKI, DHL, FedEx, dll. Untuk menghadapi pesaingan tersebut, setiap perusahaan di tuntutan untuk mampu meningkatkan daya saing dalam rangka menjaga kelangsungan hidup perusahaan (Tjiptono dan Asnastasia, 2005) dalam jurnal (Widyastuti, 2014).

Persaingan dalam jasa pengiriman barang berkaitan dengan bagaimana merebut serta mempertahankan pelanggan agar memilih dan setia untuk menggunakan jasa pengiriman mereka. Bahkan, meningkatnya jumlah masyarakat yang melakukan bisnis online membuat pesaingan perusahaan jasa pengiriman barang semakin ketat, dalam persaingan, antara perusahaan satu dengan perusahaan jasa 
pengiriman barang yang lain berlomba-lomba menawarkan keunggulan produk yang dimiliki masing-masing perusahaan. Zeithaml, Pasuraman \& Berry (Dwiyanto, 2008:145) dalam jurnal (Fitriana, Program, Ilmu, Negara, \& Airlangga, 2014) Defenisi dan kualitas pelayanan yaitu Tangibles, yaitu fasilitas fisik, peralatan, pegawai, dan fasilitas-fasilitas komunikasi yang dimiliki oleh penyedia layanan. Reability atau reabilitas adalah kemampuan untuk menyelenggarakan pelayanan secara ikhlas. Responsiveness atau responsivitas adalah kerelaan untuk menolong pengguna layanan dan menyelenggarakan pelayanan secara ikhlas. Assurance atau kepastian adalah pengetahuan, kesopanan dan kemampuan para petugas penyedia layanan dalam memberikan kepercayaan kepada pengguna layanan. Empathy adalah kemampuan memberikan perhatian kepada pengguna layanan secara individual.

Menghadapi pesaingan saat ini sangat ketat, maka PT. Pos Indonesia menerapkan strategi harga yang bersaing dimana perusahaan menawarkan harga yang lebih murah pada produknya dibandingkan dengan pesaing. Menjadikan perusahaan memiliki konsumen untuk kalangan tertentu. Namun tidak semua konsumen tertarik untuk melakukan keputusan pembelian dengan tergiur harga yang murah karena beberapa konsumen tidak mempermasalahkan harga yang lebih murah dari harga yang ditawarkan PT. Pos.

Tabel 1

Perbandingan Harga dan Lama Waktu Pengiriman Barang dari Padang ke Jakarta

\begin{tabular}{|c|c|c|c|}
\hline Jasa Kiriman & $\mathrm{Kg}$ & Harga & Lama Waktu Kirim \\
\hline Pos Indonesia & $1 \mathrm{~kg}$ & Rp. 18.000 & 1 hari \\
\hline JNE & $1 \mathrm{~kg}$ & Rp. 20.000 & 1 hari \\
\hline TIKI & $1 \mathrm{~kg}$ & Rp. 22.000 & 1 hari \\
\hline
\end{tabular}

Sumber: Wawancara Jasa Kurir

Dari tabel di atas dapat dijelaskan bahwa harga PT. Pos lebih murah dari pesaingnya tapi masih juga kalah dalam pesaingan global. Konsumen pada saat ini sudah semakin cerdas dan selektif dalam memilih suatu produk, apalagi konsumen yang memiliki tingkat pendidikan yang tinggi, sehingga mereka mendapatkan kegunaan atau manfaat yang mereka cari dari sebuah produk, bahkan mereka tidak ragu mengeluarkan biaya tinggi untuk mendapatkan produk yang memberikan rnanfaat lebih salah satunya kualitas pelayanan yang baik sesuai dengan harga yang telah ditawarkan oleh perusahaan.

PT. Pos Indonesia sudah dikenal oleh masyarakat, namun pada kenyataannya seiring dengan banyaknya kebutuhan masyarakat akan jasa pengiriman barang terutama meningkatnya masyarakat yang menjalankan bisnis online beberapa tahun terakhir ini tidak menjadikan PT. Pos sebagai pilihan utama dalam melakukan keputusan pembelian.

Banyak pembisnis online memilih jasa pengiriman barang melalui pesaing seperti JNE, TIKI, yang menawarkan harga lebih mahal dibandingkan PT. Pos. Alasan masyarakat yang melakukan bisnis online lebih memilih menggunakan JNE dan TIKI mampu memberikan kualitas pelayanan yang lebih baik. Masalah tersebut 
terbukti ketika melakukan survey awal yang dilakukan kepada konsumen jasa pengiriman barang.

\section{TINJAUAN PUSTAKA}

\section{Defenisi Inovasi}

Strategi inovasi adalah berkaitan dengan respon strategi perusahaan dalam mengadopsi inovasi (Hadjimanolis \& Dickson, 2000) dalam jurnal (Hilda, 2014) Dalam penelitian ini, peneliti menekankan dimana strategi yang memungkinkan untuk mencapai keberhasilan pada situasi dalam meningkatkan kualitas pelayanan dan kepuasan masyarakat pengguna layanan di Kantor PT. Pos Padang adalah strategi inovasi. Istilah inovasi sendiri menemukan pengertian modernnya untuk pertama kali dalam Oxford English Dictionary edisi tahun 1939 yaitu,...The act of introducing a new product into market". Dalam hal ini inovasi dipahami sebagai proses penciptaan produk (barang atau jasa) baru, pengenalan metode atau ide baru atau penciptaan perubahan atau perbaikan yang incremental (Suwarno, 2008:8) dalam jurnal (Hilda, 2014) .

Sedangkan inovasi dalam pelayanan publik dapat diartikan sebagai pembaharuan, ciptaan, kreativitas, liptaan baru dalam pelayanan publik (Setijaningrum, 2009:83) dalam jurnal (Hilda, 2014) Berdasarkan uraian diatas, strategi inovasi pelayanan publik adalah cara/upaya menerapkan terobosan-terobosan atau ide yang dilakukan oleh penyelenggara pelayanan publik untuk mencapai tujuan dan memenuhi kebutuhan penerima layanan serta memberikan kontribusi bagi pengguna layanan dalam hal kualitas pelayanan.

\section{Defenisi Kualitas Pelayanan}

Dalam pandangan Albrecht dan Zemke, kualitas pelayanan publik merupakan hasil interaksi dari berbagai aspek, yaitu sistem pelayanan, sumber daya manusia pemberi pelayanan, strategi, dan pelanggan (customers). Hubungan ke empat aspek tersebut dikenal dengan istilah segitiga pelayanan publik seperti nampak pada gambar berikut:

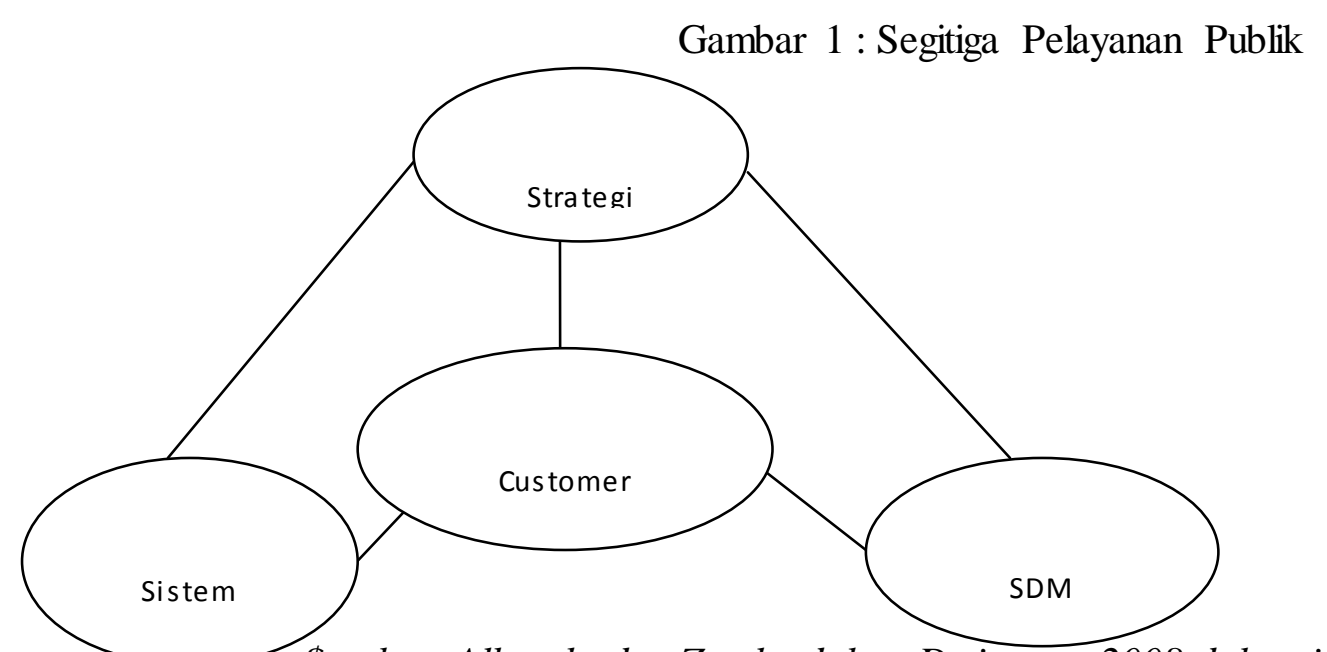

\$umber: Albrecht dan Zemke dalam Dwiyanto, 2008 dalam jurnal(Hilda, 2014)

Dari gambar di atas dapat dijelaskan bahwa sistem pelayanan publik yang baik akan menghasilkan kualitas pelayanan publik yang baik pula. Sistem yang baik akan memberikan prosedur pelayanan yang terstandar dan memberikan 
mekanisme kontrol di dalam dirinya (build in control) sehingga segala bentuk penyimpangan yang terjadi akan mudah diketahui.

Selain itu sistem pelayanan juga harus sesuai dengan kebutuhan pelanggan. Ini dapat diartikan organisasi juga harus mampu merespon kebutuhan dan keinginan dari pelanggan dengan menyediakan sistem pelayanan dan strategi yang tepat.

\section{Pengembangan Hipotesis}

\section{Pengaruh Bukti Langsung (Tangibles) Terhadap Inovasi Layanan}

Kualitas layanan adalah bentuk aktualisasi nyata secara fisik dapat terlihat atau digunakan oleh pegawai sesuai dengan penggunaan dan pemanfaatannya yang dapat dirasakan membantu pelayanan yang diterima oleh orang yang menginginkan pelayanan, sehingga puas atas pelayanan yang dirasakan, yang sekaligus menunjukkan prestasi kerja atas pemberian pelayanan yang diberikan (Parasuraman, 2001:32) dalam jurnal (Ngurah \& Adnyana, 2016). Pada suatu bentuk kualitas pelayanan yang diperhatikan perusahaan, maka terdapat suatu dimensi yang disebut dengan tangibles atau bukti langsung. Bukti langsung disini dapat diartikan sebagai bagaimana kemampuan perusahaan atau produsen dalam menunjukkan eksistensi atau kemampuannya ketika berhadapan langsung dengan konsumen. Tangibles disini tidak dapat diraba atau dilihat oleh konsumen secara langsung, akan tetapi dapat dirasakan dampaknva secara langsung dari hal-hal yang telah dilakukan perusahaan tersebut.

Dengan berpedoman dari berbagai penelitian sebelumnya yang pernah dilakukan, maka dalam penelitian ini dapat diusulkan hipotesis berupa:

$\mathrm{H}_{1}$ : Diduga (bukti fisik) berpengaruh signifikan terhadap inovasi layanan PT. Pos Indonesia cabang Padang.

\section{Pengaruh Kehandalan (Reliability) Terhadap Inovasi Layanan}

Definisi kehandalan atau reliability menurut Parasuraman (2001) dalam jurnal (Ngurah \& Adnyana, 2016) adalah setiap pegawai memiliki kemampuan yang handal, rnengetahui mengenai seluk beluk prosedur kerja, mekanisme kerja, memperbaiki berbagai kekurangan atau penyimpangan yang tidak sesuai dengan prosedur kerja dan mampu menunjukkan, mengarahkan dan memberikan arahan yang benar kepada setiap bentuk pelayanan yang belum dimengerti oleh masyarakat, sehingga memberi dampak positif atas pelayanan tersebut. Dimensi kehandalan (reliability) dalam indikator kualitas pelayanan merupakan hal penting dan vital bagi perusahaan dalam menunjukkan kinerjanya karena kehandalan merupakan bentuk ciri khas atau karakteristik dari pegawai yang memiliki prestasi kerja tinggi (Zoeldhan, 2012) dalam jurnal (Wardani et al., 2013)

Dan dari penelitian yang telah dilakukan sebelumnya dapat diajukan sebuah hipotesis:

$\mathrm{H}_{2}$ : Diduga Kehandalan (reliability) berpengaruh signifikan terhadap inovasi layanan PT. Pos Indonesia cabang Padang

Pengaruh Daya Tanggap (Responsiveness) Terhadap Inovasi Layanan

(Parasuraman, 2001) dalam jurnal (Ngurah \& Adnyana, 2016) , kegiatan melayani konsumen dengan sebaik-baiknya dalam sebuah organisasi atau perusahaan tidak sekedar tentang kehandalan perusahaan, tapi lebih ke yang bagaimana cara perusahaan menanggapi konsumen dalam bentuk apapun. 
Dari berbagai penelitian yang telah dilakukan sebelumnya maka dapat diajukan sebuah hipotesis yaitu:

$\mathrm{H}_{3}$ : Diduga Daya Tanggap (responsiveness) berpengaruh signifikan terhadap inovasi layanan PT. Pos Indonesia cabang Padang

\section{Pengaruh Jaminan (assurance) terhadap Inovasi Layanan}

Bentuk jaminan yang lain yaitu jaminan terhadap pegawai yang memiliki perilaku kepribadian (personality behavior) yang baik dalam memberikan pelayanan, tentu akan berbeda pegawai yang memiliki watak atau karakter yang kurang baik dan yang kurang baik dalam memberikan pelayanan (Margaretha, 2003 : 201) dalam jurnal (Publik \& Agustus, 2015). Assurance atau jaminan diatas meliputi kemampuan karyawan atas pengetahuan terhadap produk secara tepat, kualitas, keramahtamahan, perhatian, dan kesopanan memberi pelayanan, keterampilan dalam memberikan informasi, kemampuan dalam memberikan keamanan dalam memanfaatkan jasa yang ditawarkan, dan kemampuan dalam menanamkan kepercayaan pelanggan terhadap perusahaan (Zeithmal dkk, 1990) dalam jurnal (Ngurah \& Adnyana, 2016).

Oleh karena itu dari berbagai penelitian yang telah dilakukan sebelumnya, maka dapat diusulkan sebuah hipotesis sebagai berikut:

$\mathrm{H}_{4}$ : Diduga Jaminan (assurance) berpengaruh signifikan terhadap inovasi layanan PT. Pos Indonesia cabang Padang.

\section{Pengaruh Empati (Emphaty) Terhadap Inovasi Layanan}

Definisi empati dalam pemasaran menurut Nursodik (2010) dalam jurnal (Ngurah \& Adnyana, 2016) adalah perhatian secara individual yang diberikan perusahaan kepada pelanggan seperti kemudahan dalam menghubungi perusahaan, kemampuan karyawan untuk berkomunikasi dengan pelanggan, dan kebutuhan pelanggannya. Pelayanan akan berjalan dengan lancar dan berkualitas apabila setiap pihak yang berkepentingan dengan pelayanan memiliki adanya rasa empati (empathy) dalam menyelesaikan atau mengurus atau memiliki komitmen yang sama terhadap pelayanan (Parasuraman, 2001:40) dalam jurnal (Ngurah \& Adnyana, 2016).

Dari uraian diatas maka berdasarkan berbagai penelitian yang telah dilakukan sebelumnya dapat diajukan sebuah hipotesis sebagai berikut:

$\mathrm{H}_{5}$ : Diduga Empati (emphaty) berpengaruh signifikan terhadap inovasi layanan PT. Pos Indonesia cabang Padang.

\section{METODE PENELITIAN}

\section{Jenis Penelitian}

Jenis penelitian adalah suatu atribut atau sifat atau nilai dari orang, objek, atau kegiatan yang mempunyai variasi tertentu yang ditetapkan oleh peneliti untuk dipelajari dan ditarik kesimpulannya (Sugiyono, 2007). Jenis penelitian yang dipakai adalah penelitian kuantitatif, penelitian kuantitatif mengukur data kuantitatif dan statistik objektif melalui perhitungan ilmiah berasal dari sampel orang - orang atau penduduk yang diminta menjawab atas sejumlah pertanyaan survei untuk menentukan frekuensi dan persentase, Teknik pengambilan sampel pada umumnya dilakukan secara random, pengumpulan data menggunakan 
instrumen penelitian, analisa data bersifat kuantitatif/statistik dengan tujuan untuk menguji hipotesis yang ditetapkan.

\section{Objek Penelitian}

Objek dalam penelitian ini adalah Konsumen PT. Pos Indonesia cabang Padang

\section{Populasi dan Sampel}

Popupali dalam penelitian ini adalah selurh konsumen kantor Pos cabang Padang jumlah populasi dalam penelitian ini sampai pada akhir tahun 2017 sebanyak 312 konsumen, mengingat keterbatasan waktu,biaya dan tenaga maka tidak memungkinkan untuk meneliyi semua populasi yang ada, sehingga dalam penelitian ini diambil sampel nya saja, metode pengambilan sampel menggunakan metode solvin (Umar,2005).

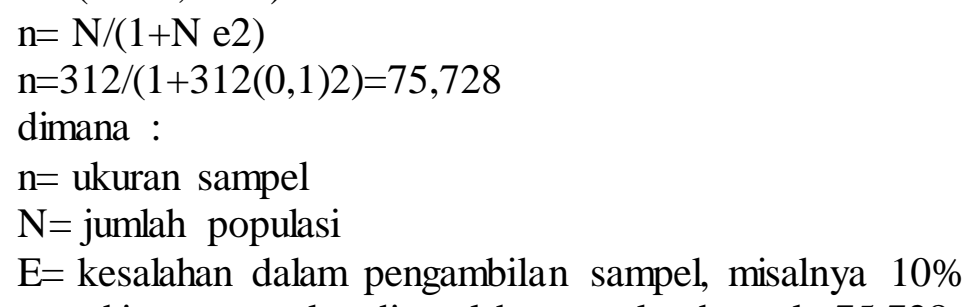

Berdasarkan perhitungan, maka diperoleh sampel sebanyak 75,728 dan dibulatkan 76 responden jadi sampel dalam penelitian ini adalah 76 responden $(n=76)$. Berdasarkan pendapat Roscoe(2001) sampel penelitian sudah dianggap mencukupi.

\section{Jenis dan Sumber Data}

Adapun data yang digunakan dalam penelitian ini adalah kualitatif dan kuantitatif.

\section{Teknik Pengumpulan Data}

Menurut Sutopo (2006: 9), metode pengumpulan data dalam penelitian kualitatif secara umum dikelompokan ke dalam dua jenis cara, yaitu teknik yang bersifat interaktif dan non-interaktif. Metode interaktif meliputi interview dan observasi berperan serta, sedangkan metode non-interaktif meliputi observasi tidak berperan serta, teknik kuesioner, mencatat dokumen, dan partisipasi tidak berperan.

Teknik yang dipakai dalam penelitian ini adalah Teknik koesioner, dalam hal ini pengumpulan data yang dilakukan dengan cara memberikan seperangkat pertanyaan atau pernyataan tertulis kepada responden untuk dijawabnya, dimana peneliti tidak langsung bertanya jawab dengan responden (Sutopo, 206:87).

\section{Uji Validitas}

Uji validitas menurut Nugroho ( 2005 : 67 ) digunakan untuk mengetahui kelayakan butir - butir dalam daftar pertanyaan atau pernyataan dalam mendefinisikan variabel. Daftar pernyataan ini pada umumnya mendukung suatu kelompok variabel tertentu. Jadi dapat dikatakan, semakin tinggi validitas suatu alat ukur maka alat ukur tersebut semakin mengenai pada sasarannya atau semakin menunjukan apa yang seharusnya diukur. Suatu alat ukur dapat dikatakan mempunyai validitas tinggi apabila dapat dijalankan fungsi ukurnya atau memberikan hasil ukur yang sesuai dengan maksud dan tujuan dari diadakannya tes atau penilaian tersebut.

Validitas suatu butir pernyataan dapat dilihat pada hasil output statistical program for social science (SPSS) pada tabel dengan judul item-total statistic. Menilai 
kevalidtan masing - masing butir pernyataan dapat dilihat dari nilai corrected item-total correlation masing - masing butirpernyataan. Suatu butir pernyataan dikatakan valid jika nilai dari corrected item-total correlation> 0,300. Uji validitas sebaiknya dilakukan secara terpisah pada lembar kerja yang berbeda antara satu konstruk variabel dengan konstruk variabel lain sehingga dapat diketahui butir - butir variabel mana yang paling banyak tidak valid. Sehingga pengambilan keputusan adalah :

a. jikacorrected item-total correlation> 0,300 maka dimensi tersebut valid.

b. jikacorrected item-total correlation $\leq 0,300$ maka dimensi tersebut tidak valid.

Uji Reliabilitas

Uji reliabilitas keandalan ) menurut Nugruho ( 2005 : 72 ) merupakan ukuran suatu kestabilan dan konsistensi responden dalam menjawab hal yang berkaitan dengan pernyataan yang merupakan dimensi suatu variabel dan disusun dalam suatu bentuk koesioner. Uji reabilitas dapat dilakukan secara bersama - sama terhadap seluruh butir pernyataan untuk lebih dari satu variabel, namun sebaiknya uji reliabilitas sebaliknya dilakukan pada masing - masing variabel pada lembar kerja yang berbeda sehingga dapat diketahui konstruk variabel mana yang tidak reliabel. Reliabilitas suatu konstuk variabel dikatakan baik jika memiliki nilai Cronbach's Alpha> 0,06. Sehingga pengambilan keputusan adalah.

a. Jika $r$ Alpha positif, serta $r>0,06$ maka dimensi tersebut reliabel.

b. Jika $r$ Alpha positif, serta $r \leq 0,06$ maka dimensi tersebut tidak reliabel.

\section{Uji Asumsi Klasik}

Ada tiga asumsi yang terpenting sebagai syarat penggunaan metode. Asumsi klasik tersebut adalah asumsi normalitas, Multikolinearitas, dan heterokedastisitas.

\section{Uji Normalitas}

Uji Normalitas data uji normalitas bertujuan untuk menguji apakah dalam model regresi, variabel independen dan variabel dependen keduanya mempunyai distribusi normal ataukah tidak (Ghozali, 2006:110). Model regresi yang baik adalah memiliki distribusi data normal atau mendekati normal. Uji normalitas data ini dilakukan dengan menggunakan analisis uji normalitas, cara ini dilakukan dengan menggunakan uji Kolmogrov Smirnov yaitu:

- jika nilai signifikan > alpha (a) distribusi adalah normal

- jika nilai signifikan < alpha (a) distribusi adalah tidak normal

\section{Uji Heteroskedasitas.}

Uji Heteroskedasitas digunakan untuk menganalisis apakah terjadi ketidaksamaan variance dari residual satu pengamatan ke pengamatan lain (Santoso, 2015). Salah satu syarat yang harus dipenuhi dalam model regresi adalah tidak terjadinya heteroskedasitas (Atmaja, 2009). Untuk mendeteksi ada tidaknya heteroskedasitas dapat dianalisis dengan menggunakan uji Gletser. Jika hasil uji Gletser menunjukan nilai signifikan lebih besar dari nilai signifikan yang digunakan dalam penelitian yaitu 0,05 maka tidak terjadi heteroskedasitas, sebaliknya jika nilai signifikan hasil perhitungan lebih kecil dari 0,05 maka terjadi gejala heteroskedasitas. 


\section{Uji Multikolinieritas}

Uji Multikolinearitas bertujuan untuk menguji apakah model regresi ditemukan adanya korelasi antar variabel bebas (independen). Model regresi yang baik seharusnya tidak terjadi korelasi diantara variabel bebas (independen). Untuk mengetahui ada tidaknya multikolinearitas adalah dengan melihat : (1) nilai tolerance, (2) variance inflation factor (VIF). Jika VIF lebih besar dari 10 dan tolerance kurang dari 0,1 maka indikasi yang terjadi multikolinearitas (Ghozali, 2006:91).

\section{Analisa Regresi Berganda}

Untuk mengetahui Tidak adanya pengaruh variabel faktor - faktor yang mempengaruhi Tangibel ( X1), Emphaty (X2), Reliability (X3), Responsiveness (X4) dan Assurance ( $\mathrm{X} 5$ ) terhadap Inovasi layanan ( $\mathrm{Y}$ ) maka peneliti menggunakan analisa regresi linear berganda. Persamaan yang digunakan :

$$
\mathrm{Y}=\mathrm{a}+\mathrm{b}_{1} \mathrm{X}_{1}+\mathrm{b}_{2} \mathrm{X}_{2}+\mathrm{b}_{3} \mathrm{X}_{3}+\mathrm{b}_{4} \mathrm{X}_{4}+\mathrm{b}_{5} \mathrm{X}_{5}+\mathrm{e}
$$

untuk mendapatkan nilai persamaan regresi yaitu nilai a dan $b$ maka penengolahan data dilakukan menggunakan program SPSS.

\section{Uji Hpotesis}

\section{Uji F (Uji Simultan)}

Uji $F$ dilakukan untuk mengetahui apakah ada pengaruh yang positif dan signifikan secara simultan atau bersama - sama antara variabel bebas dengan terikat, pengujian ini dengan menggunakan tingkat resiko sebesar $5 \%(\alpha=0,05)$. Pada uji ini digunakan rumus :

Fhitung $=\frac{R^{2} /(\mathrm{K}-1)}{\left(1-R^{2}\right) /(\mathrm{N}-\mathrm{K})}$

Dimana : $R^{2} \quad=$ koefisien determinasi

$\mathrm{n} \quad=$ Jumlah Sampel

$\mathrm{k} \quad=$ Jumlah Variabel Bebas

dari rumus diatas maka diperoleh nilai probabilitas yang dibandingkan dengan $\alpha$. Jika nilai probabilitas lebih besardari $\alpha=50 \%$ yang dapat dilihat dari hasil analisa Regresi berganda, maka keputusannya adalah ditolak, sebaliknya jika nilai probabilitas kecil dari $\alpha=5 \%$ maka keputusan nya adalah Hipotesis diterima.

\section{Uji T (Uji t)}

Uji t digunakan untuk menguji koefisien regresi secara parsial dari variabel bebas terhadap variabel terikat. Pengujian ini menggunakan tingkat resiko sebesar $5 \%$ $(\alpha=0,05)$. Pada uji ini digunakan rumus :

$$
t=\frac{\bar{X}_{1}-\bar{X}_{2}}{\sqrt{\frac{\left(n_{1}-1\right) S_{1}^{2}+\left(n_{2}-1\right) S_{2}^{2}}{n_{1}+n_{2}-2}\left(\frac{1}{n_{1}}+\frac{1}{n_{2}}\right)}}
$$

Dari rumus diatas maka diperoleh nilai probabilitas dengan tingkat resiko tertentu. Jika nilai probabilitas lebih besar dari $\alpha=5 \%$ maka keputusannya adalah Hipotesis di tolak.sebaliknya jika nilai probabilitas kecil dari $\alpha=5 \%$ maka keputusan nya adalah Hipotesis diterima.

\section{Uji Koefisien Determinasi ( $\mathbf{R}^{2}$ )}

Koefesiensi determinasi $\left(\mathrm{R}^{2}\right)$ pada intinya mengukur seberapa jauh kemampuan model dalam menerangkan variasi independen.Nilai koefisien determinasi adalah antara nol dan satu.Nilai $\mathrm{R}^{2}$ yang kecil berarti kemampuan variabel-variabel 
independen dalam menjelaskan variasi variabel dependen sangat terbatas. Nilai yang mendekati satu berarti variabel-variabel independen memberikan hampir semua informasi yang dibutuhkan untuk memprediksi variasi variabel dependen ( Ghozali, 2001 ). Koefisien determinasi merupakan proporsi hubungan antara Y dan X. Nilai koefisien determinasi adalah diantara 0 (nol) dan 1 (satu). Koefisien determinasi dilakukan untuk mendeteksi ketepatan yang paling baik dalam analisis regresi ini, yaitu dengan membandingkan besarnya nilai koefisien determinasi, jika $\mathrm{R}^{2}$ semakin besar mendekati 1 (satu) maka model semakin tepat.

\section{HASIL DAN PEMBAHASAN}

\section{Uji Regresi Linear Berganda}

Analisis regresi berganda digunakan untuk mengetahui hubungan atau pengaruh antara dua atau lebih variabel bebas (X) dengan satu variabel tergantung (Y) yang ditampilkan dalam bentuk persamaan regresi, Analisis bertujuan untuk memprediksi nilai dari variabel tergantung apabila nilai variabel bebas mengalami kenaikan atau penurunan dan untuk mengetahui arah hubungan. Hasil olah data untuk regresi linear berganda untuk semua variabel dapat dilihat pada tabel 1 .

\section{Tabel 1}

Hasil Uji Linear Berganda

\begin{tabular}{|cc|c|c|c|}
\hline \multirow{2}{*}{\multicolumn{2}{|c|}{ Model }} & \multicolumn{2}{|c|}{ Unstandardized Coefficients } & Standardized Coefficients \\
\cline { 2 - 5 } & B & Std. Error & Beta \\
\hline 1 & (Constant) & 24.169 & 4.563 & \\
& x1 & -.125 & .142 & -.112 \\
& x2 & -.126 & .214 & -.072 \\
& x3 & -.443 & .219 & -.254 \\
& x4 & .310 & .162 & .237 \\
& x5 & .197 & .123 & .187 \\
\hline
\end{tabular}

Sumber : Data pengolahan SPSS.06 (lampiran3)

Dari tabel diatas,dapat disimpulkan notasi atau persamaah regresi linear berganda yang diperoleh adalah :

$\mathrm{Y}=\mathrm{a}+\mathrm{b} 1 \mathrm{X} 1+\mathrm{b} 2 \mathrm{X} 1+\mathrm{b} 3 \mathrm{X} 3+\mathrm{b} 4 \mathrm{X} 4+\mathrm{b} 5 \mathrm{X} 5+\mathrm{e}$

$\mathrm{Y}=24.169-0,125 \mathrm{X}_{1}-0,126 \mathrm{X}_{2}-0,443 \mathrm{X}_{3}+0,310 \mathrm{X}_{4}+0,197 \mathrm{X}_{5}+\mathrm{e}$

Keterangan

$\mathrm{Y}$ : Inovasi Layanan

$\mathrm{X}_{1}$ : Tangibel

$\mathrm{X}_{2}$ :Emphaty

$\mathrm{X}_{3}$ : Reliability

$\mathrm{X}_{4}$ : Responsivenes

$\mathrm{X}_{5}$ : Assurance

e : Error

Persamaan regresi tersebut memberikan gambaran bahwa : 
1. Nilai konstan sebesar 24.169 berarti jika nilai variabel Tangibel, Emphaty, Reliabilty, Responsiveness dan Assurance jika nilai nol, maka nilai dari variabel Inovasi layanan adalah 24.169

2. Variabel Tangibel mempunyai nilai konfisien regresi sebesar -0,125, yang berarti jika variabel independen lain bernilai tetap atau tidak berubah, maka setiap Penurunan 1 satuan variabel Tangibel, variabel Tangibel akan mengalami penurunan $-0,125$ konfisien bernilai negatif artinya Tangibel mempunyai pengaruh negatif terhadap Inovasi Layanan.

3. Variabel Emphaty mempunyai nilai konfisien regresi sebesar $-0,126$ yang berarti jika variabel independen lain bernilai tetap atau tidak berubah, maka setiap Penurunan 1 satuan variabel Emphaty, variabel Emphaty akan mengalami penurunan $-0,126$ konfisien bernilai negatif artinya Emphaty mempunyai pengaruh positif terhadap Inovasi Layanan. Jika Emphaty ditingkatkan dengan baik maka akan semakin meningkat kualitas pelayanannya.

4. Variabel Reliability mempunyai nilai konfisien regresi sebesar -0,443, yang berarti jika variabel independen lain bernilai tetap atau tidak berubah, maka setiap Penurunan 1 satuan variabel Reliability, variabel Reliability akan mengalami penurunan $-0,443$ konfisien bernilai negative. artinya Reliability mempunyai pengaruh negatif terhadap Inovasi Layanan.

5. Variabel Responsiveness mempunyai nilai konfisien regresi sebesar 0,310, yang berarti jika variabel independen lain bernilai tetap atau tidak berubah, maka setiap kenaikan 1 satuan variabel Responsiveness, variabel Responsiveness akan mengalami peningkatan 0,310 konfisien bernilai positif artinya Responsiveness mempunyai pengaruh positif terhadap Inovasi Layanan. Jika Responsiveness ditingkatkan dengan baik maka akan semakin meningkat kualitas pelayanannya.

6. Variabel Assurance mempunyai nilai konfisien regresi sebesar 0,197, yang berarti jika variabel independen lain bernilai tetap atau tidak berubah, maka setiap kenaikan 1 satuan variabel Assurance, variabel Assurance akan mengalami peningkatan 0,197 konfisien bernilai positif artinya Assurance mempunyai pengaruh positif terhadap Inovasi Layanan. Jika Assurance ditingkatkan dengan baik maka akan semakin meningkat kualitas pelayanannya.

\section{Uji Hipotes is}

\section{Uji F}

Uji $\mathrm{F}$ dilakukan untuk membuktikan apakah terdapat pengaruh antara variabel $\mathrm{X}$ dengan variabel $\mathrm{Y}$ secara silmutan. Hasil uji $\mathrm{F}$ untuk variabel Kualitas pelayanan berpengaruh terhadap Inovasi layanan dapat dilihat pada tabel 2 
Tabel 2

Hasil Uji F

\begin{tabular}{|ll|l|l|l|l|l|}
\hline Model & Sum of Squares & Df & Mean Square & F & Sig. \\
\hline 1 & Regression & 109.245 & 5 & 21.849 & 2.737 & $.026^{\mathrm{a}}$ \\
& Residual & 558.794 & 70 & 7.983 & & \\
\multicolumn{1}{|l|}{ Total } & 668.039 & 75 & & & \\
\hline
\end{tabular}

Sumber : Data pengolahan SPSS.16 (lampiran3)

Nilai $F$ hitung sebesar 2.541 yang segnifikan 0,026. Karena sig > 0,05 ini berarti rumusan hipotesis yang menyatakan seluruh variabel Kualitas pelayanan Tangibel, Emphaty, Reliability, Responsiveness dan Assurance berpengaruh terhadap Inovasi layanan.

\section{Uji Koefisien Determinasi $\left(\mathbf{R}^{2}\right)$}

Uji Koefisien Determinasi $\left(\mathrm{R}^{2}\right)$ digunakan untuk mengetahui jumlah atau presentase sumbangan pengaruh variabel bebas dan variabel terikat dalam metode regresi yang secara serentak atau bersama-sama memberikan pengaruh terhadap variabel tidak bebas.

Jadi koefisien angka yang ditunjukan memperlihatkan sejauh mana model yang terbentuk dapat menjelaskan kondisi yang sebenarnya. Hasil Uji Koefisien Determinasi $\left(\mathrm{R}^{2}\right)$ dapat dilihat pada tabel 3

Tabel 3

\section{Uji Koefisien Determinasi $\left(\mathbf{R}^{2}\right)$}

Model Summary

\begin{tabular}{|l|l|l|l|l|}
\hline Model & $\mathrm{R}$ & $\mathrm{R}$ Square & Adjusted R Square & Std. Error of the Estimate \\
\hline 1 & $.404^{\mathrm{a}}$ & .164 & .104 & 2.82538 \\
\hline
\end{tabular}

Sumber : Data pengolahan SPSS.16 (lampiran3)

Pada tabel diatas diperoleh nilai adjusted $\mathrm{R}^{2}$ square adalah 0,104 artinya sebesar $10,4 \%$ variabel Tangibel, Emphaty, Responsiveness dan Assurance mampu menjelaskan variabel Inovasi layanan ,dan sisanya 89,6\% dipengaruhi oleh faktor lain yan tidak diteliti dalam penelitian ini seperti pengaruh harga, citra dan produk.

Uji T

Uji $\mathrm{T}$ digunakan untuk mengetahui pengaruh variabel independen $\mathrm{X}$ (bebas) terhadap variabel dependen $\mathrm{Y}$ (variabel terikat). Hasiil uji $\mathrm{T}$ untuk variabel Tangibel, Emphaty, Responsiveness dan Assurance tarhadap Inovasi layanan. Uji Hipotesis menggunakan Uji $\mathrm{T}$ untuk mengetahui pengaruh variabel independen secara parsial derhadap variabel dependen dengan membandingkan nilai $T$ signifikan dengan taraf nyata $95 \%$ penelitian ini menggunakan probabilitas tarif nyata $95 \%$ atau $a=0,05$ sehingga dapat diketahui pengaruh variabel bebas ssecara individu dengan kreteria jika $\mathrm{t}$ signifikan $<\alpha=0,05$ maka dapat diketahui variabel bebas berpengaruh segnifikan terhadaap variabel terikat.

Jika $\mathrm{t}$ signifikan $>\alpha=0.05$ maka dapat diketahui varabel bebass tidak mengetahui signifikan terhadap variabel terikat dan membandingkan probabilitas pada tarafnya 95\% dari koefisien parsial (r) sehingga dapat diketahui pengaruh variabl 
bebas secara induvidu dengan menggunakan kretria uji hipotesis dengan uji $\mathrm{t}$ sebagai berikut :

- Thitung < ttabel (0.05), maka Ho diterima sehingga Ha ditolak

- $\quad$ Thitung > ttabel (0.05), maka Ho ditolak sehingga Ha diterima

Hasil pengujian hipotesis secara persial dapat dilihat dalam tabel 4.23 dibawah ini:

Tabel 4

Hassil Uji T

\begin{tabular}{|l|l|l|}
\hline \multicolumn{1}{|l|}{ Model } & \multicolumn{1}{|l|}{ T } & Sig. \\
\hline $1 \quad$ (Constant) & 5.297 & .000 \\
x1 Tangibel & -.882 & .381 \\
x2 Emphaty & -.590 & .557 \\
x3 Reliability & -2.028 & .046 \\
x4 Responsiveness & 1.913 & .060 \\
x5 Assurance & 1.606 & .113 \\
\hline
\end{tabular}

Sumber : Data SPSS.16 (lampiran3)

Dari tabel 4.23 dapat disimpulkan sebagai berikut :

1. Uji pasial variabel kualitas pelayanan Tangibel terhadap variabel Inovasi layanan dari hasil pengujian yang dilakukan dan nampak pada tabel 4.23 diperoleh thitung $(-0,882)<\mathrm{t}$ tabel $(1,66571)$, Maka Ho ditolak sehingga Ha diterima, hal ini menunjukan adanya negatif dan tidak signifikan pengaruh variabel kualitas pelayanan Tangibel terhadap variabel Inovasi layanan.

2. Uji pasial variabel kualitas pelayanan Emphaty terhadap variabel Inovasi layanan dari hasil pengujian yang dilakukan dan nampak pada tabel 4.23 diperoleh thitung $(-0,590)<\mathrm{t}$ tabel $(1,66571)$, Maka Ho ditolak sehingga Ha diterima, hal ini menunjukan adanya negatif dan tidak signifikan pengaruh variabel kualitas pelayanan Emphaty terhadap variabel Inovasi layanan.

3. Uji pasial variabel kualitas pelayanan Reliability terhadap variabel Inovasi layanan dari hasil pengujian yang dilakukan dan nampak pada tabel 4.23 diperoleh thitung $(-2,028)<\mathrm{t}$ tabel $(1,66571)$, Maka Ho ditolak sehingga Ha diterima, hal ini menunjukan adanya negatif dan tidak signifikan pengaruh variabel kualitas pelayanan Reliability terhadap variabel Inovasi layanan.

4. Uji pasial variabel kualitas pelayanan Responsiveness terhadap variabel Inovasi layanan dari hasil pengujian yang dilakukan dan nampak pada tabel 4.23 diperoleh thitung (1.913) $>\mathrm{t}$ tabel (1,66571), Maka Ho diterima sehingga Ho ditolak, hal ini menunjukan adanya positif dan signifikan pengaruh variabel kualitas pelayanan Responsiveness terhadap variabel Inovasi layanan adalah signifikan. 
5. Uji pasial variabel kualitas pelayanan Assurance terhadap variabel Inovasi layanan dari hasil pengujian yang dilakukan dan nampak pada tabel 4.23 diperoleh thitung $(1.606)<\mathrm{t}$ tabel $(1,66571)$, Maka Ho ditolak sehingga Ho diterima, ini adanya positif dan tidak signifikan pengaruh variabel kualitas pelayanan Assurance terhadap variabel Inovasi layanan.

\section{Pembahasan}

\section{Pengaruh Kualitas Pelayanan (Tangibel) Terhadap Inovasi Layanan}

Dari uji regresi berganda dapat dapat dilihat dari variabel nilai regresi Tangibel sebesar -0,882 yang berarti jika variabel independen lain nya bernilai tetap atau tidak berubah, maka setiap penurunan 1 satuan veriabel krakteristik Kualitas pelayanan Tangibel, variabel Inovasi layanan akan mengalami penurunan sebesar -0,882 dan hasil uji $\mathrm{T}$ juga diperoleh tingkat variabel kualitas pelayanan Tangibel sebesar $0,381>\mathrm{a}=0,05$ ( level of signifikan). Hal ini menunjikan adanya pengaruh positif dan tidak segnifikan pengaruh variabel Kualitas pelayanan Tangibel terhadap Inovasi layana.

Hal ini melakukan adanya penjelasan yang bijaksana, mendital, membina, mengarahkan dan membujuk agar menyikapi segala bentuk-bentuk presedur dan mekanisme kerja yang berlaku dala, suatu organisasi, sehingga bentuk pelayanan mendapatkan respon positif (Parasuraman, 2001 :52) dalam jurnal (Ngurah \& Adnyana, 2016)

Pengaruh Kualitas Pelayanan (Emphaty) Terhadap Inovasi Layanan

Dari uji regresi berganda dapat dapat dilihat dari variabel nilai regresi Emphaty sebesar -0,590 yang berarti jika variabel independen lain nya bernilai tetap atau tidak berubah, maka setiap penurunan 1 satuan veriabel krakteristik Kualitas pelayanan Emphaty, variabel Inovasi layanan akan mengalami penurunan sebesar -0,590 dan hasil uji $\mathrm{T}$ juga diperoleh tingkat variabel kualitas pelayanan Emphaty sebesar $0,557>\mathrm{a}=0,05$ ( level of signifikan). Hal ini menunjikan adanya pengaruh negatif dan tidak segnifikan pengaruh variabel Kualitas pelayanan Emphaty terhadap Inovasi layanan.

Pelayanan akan berjalan dengan lancer dan berkualitas apabila setiappihak yang berkepentingan dengan pelayanan memiliki adanya rasa empati dalam menyelesaikan atau mengurus dan memiliki komitmen yang sama terhadap pelayanan (Parasurman, 2001:40).

\section{Pengaruh Kualitas Pelayanan (Reliability) Terhadap Inovasi Layanan}

Dari uji regresi berganda dapat dapat dilihat dari variabel nilai regresi Reliability sebesar -2.028 yang berarti jika variabel independen lain nya bernilai tetap atau tidak berubah, maka setiap penurunan 1 satuan veriabel krakteristik Kualitas pelayanan Reliability, variabel Inovasi layanan akan mengalami penurunan sebesar -2.028 dan hasil uji $\mathrm{T}$ juga diperoleh tingkat variabel kualitas pelayanan Reliability sebesar $0,046<\mathrm{a}=0,05$ (level of signifikan). Hal ini menunjikan adanya pengaruh negative dan segnifikan pengaruh variabel Kualitas pelayanan Reliability terhadap Inovasi layana adalah segnifikan.

Dalam indicator kualitas pelayanan merupakan hal penting dan vital bagi perusahaan dalam menunjukan kinerja karena kehandaln merupakan bentuk chirikhas atau kerakteristik dari pegawai yang memiliki prestasi kerja tinggi (Zoeldhan, 2012) dalam jurnal (Ngurah \& Adnyana, 2016) 


\section{Pengaruh Kualitas Pelayanan (Responsiveness) Terhadap Inovasi Layanan}

Dari uji regresi berganda dapat dapat dilihat dari variabel nilai regresi Responsiveness sebesar 1.913yang berarti jika variabel independen lain nya bernilai tetap atau tidak berubah, maka setiap kenaikan 1 satuan veriabel krakteristik Kualitas pelayanan Responsiveness, variabel Inovasi layanan akan mengalami peningkatan sebesar 1.913 dan hasil uji $\mathrm{T}$ juga diperoleh tingkat variabel kualitas pelayanan Responsiveness sebesar 0,060 > a $=0,05$ (level of signifikan). Hal ini menunjikan adanya pengaruh positif dan tidak segnifikan pengaruh variabel Kualitas pelayanan Responsiveness terhadap Inovasi layanan.

Membantu pelayanan yang diterima oleh orang yang menginginkan pelayanan, sehingga puas atas pelayanan yang dirasakan, yang sekaligus menunjukan prestasi kerja atas pemberian pelayanan yang diberikan (Parasuraman, 2001 :32).

\section{Pengaruh Kualitas Pelayanan (Assurance) Terhadap Inovasi Layanan}

Dari uji regresi berganda dapat dapat dilihat dari variabel nilai regresi Assurance sebesar 1.606yang berarti jika variabel independen lain nya bernilai tetap atau tidak berubah, maka setiap kenaikan 1 satuan veriabel krakteristik Kualitas pelayanan Assurance, variabel Inovasi layanan akan mengalami peningkatan sebesar 1.606dan hasil uji $\mathrm{T}$ juga diperoleh tingkat variabel kualitas pelayanan Assurance sebesar $0,113>\mathrm{a}=0,05$ (level of signifikan). Hal ini menunjikan adanya pengaruh positif dan tidak segnifikan pengaruh variabel Kualitas pelayanan Assurance terhadap Inovasi layanan.

Bahwa segala bentuk urusan pelayanan yang diberikan akan tuntas dan selesai dengan kecepatan, ketepatan, kemudahan, kelancaran dan kualitas pelayanan yang diberikan (Parasurman, $2001: 69$ ).

\section{DAFTAR PUSTAKA}

Anggraeny, C. (2013). Inovasi Pelayanan Kesehatan dalam Meningkatkan Kualitas Pelayanan di Puskesmas Jagir Kota Surabaya. Kebijakan Dan Manajemen Publik, 1, 85-93.

Aziz, N. (2019). Pengaruh Biaya, Angsuran Dan Kualitas Pelayanan Terhadap Kepuasan Nasabah Pembiayaan Bmt At-Taqwa Muhammadiyah Cabang Siteba Padang. https://doi.org/10.17605/OSF.IO/YVJAS

Aziz, N. (2019). Pengaruh Kualitas Layanan Terhadap Kepuasan Nasabah SMS Banking Pada Bank Nagari Cabang Pembantu RSUP DR M Djamil Padang. https://doi.org/10.17605/OSF.IO/S3JVG

Fernandes, Y. D., \& Marlius, D. (2018). Peranan Customer Service Dalam Meningkatkan Pelayanan Kepada Nasabah Pada PT. Bank Pembangunan Daerah Sumatera Barat Cabang Utama Padang. https://doi.org/10.31227/osf.io/wrh3p

Fernos, J., \& Putra, Y. E. (2019). Analisa Pengaruh Kualitas Pelayanan Terhadap Kepuasan Nasabah Pada PT. Bank Mega Syari'ah Padang. https://doi.org/10.31219/osf.io/y2baf 
Fitriana, D. N., Program, M., Ilmu, S., Negara, A., \& Airlangga, U. (2014). Inovasi Pelayanan Publik BUMN ( Studi Deskriptif tentang Inovasi Boarding Pass System dalam Meningkatkan Kualitas Pelayanan Kereta Api PT KAI di Stasiun Gubeng Surabaya ) Diah Nur Fitriana, 2, 1-10.

Hilda, N. (2014). Strategi Inovasi Layanan dalam Meningkatkan Kualitas Pelayanan di Kantor Pertanahan Kota Surabaya II. Kebijakan Dan Manajemen Publik, 2(1), 1-10. Retrieved from http:/journal.unair.ac.id/download-fullpapers-kmpdd76ece88cfull.pdf

Marlius, D. (2018). Loyalitas Nasabah Bank Nagari Syariah Cabang Bukittinggi Dilihat Dari Kualitas Pelayanan. Jurnal Pundi. Volume 1. No. 3. Hal.12-22. https://doi.org/10.31575/jp.v1i3.60

Marlius, D. (2018). Pengaruh Dimensi Kualitas Pelayanan Website Akademik Terhadap Kepuasan Mahasiswa Pada STIE “KBP”. Jurnal Ipteks Terapan. Volume 12. No. 2. Hal. 116-128. http://doi.org/10.22216/jit.2018.v12i2.633

Muslichati, E. Z. (2015). Pengaruh Kualitas Layanan dan Inovasi Layanan Terhadap Kepuasan Konsumen Pada Rumah Sakit Buah Hati Kudus, 1(2), 341-347.

Ngurah, K., \& Adnyana, D. (2016). Tangible , Reliability , Responsiveness , Assurance , Emphaty Pada Inovasi Layanan Terhadap Kepuasan Wajib Pajak Studi Kasus Pada Samsat Corner Tiara, 13, 32-59.

Publik, M., \& Agustus, M. (2015). Kualitas Pelayanan Transportasi Publik ( Studi Deskriptif Tentang Kualitas Pelayanan Kapal Penumpang Trayek Gresik Bawean di Pelabuhan Gresik ) Setio Aji Andiri, 3, 1-7.

Putra, Y. E., \& Aziz, N. (2019). Pengaruh Kualitas Pelayanan Dan Kepuasan Pelanggan Terhadap Loyalitas Nasabah PT. Bank Rakyat Indonesia Cabang Padang. https//doi.org/10.31219/osf.io/hcsw2

Syamsuddien, M. A. L. I. (2016). Inovasi Layanan Pt Pos Indonesia Dalam Upaya Menjaga Eksistensi Di Era Persaingan ( Studi Pada Kantor Pos Bandar Lampung ) Skripsi Oleh.

Tiza, M. F., \& Susanti, F. (2019). Pengaruh Kualitas Pelayanan Terhadap Kepuasan Pelanggan, Studi kasus pada perusahaan JNE Cabang Padang. https://oi.org/10.31227/osf.io/hx87m

Ulfa, M., \& Mayliza, R. (2019). Pengaruh Kualitas Pelayanan Dan Kepuasan Pelanggan Terhadap Loyalitas Pelanggan PDAM Kota Padang. https://doi.org/10.31219/osf.io/spmgv 
Wardani, E. K., Sundarso, \& Warsono, H. (2013). Kualitas Pelayanan Bus Rapid Trans ( BRT ) Kota Semarang.

Widyastuti, B. (2014). Analisis Kualitas Pelayanan Perizinan Investasi di UPT Pelayanan Perizinan Terpadu ( P2T ) Provinsi dalam Meningkatkan Investasi di Jawa Timur, 1, 1-8. 